\title{
Depression trajectories of older Americans and Britons 2002 - 2012: A rejoinder and a hope
}

DOI:

10.1016/j.jagp.2017.07.010

\section{Document Version}

Accepted author manuscript

Link to publication record in Manchester Research Explorer

\section{Citation for published version (APA):}

Tampubolon, G., \& Maharani, A. (2017). Depression trajectories of older Americans and Britons 2002 - 2012: A rejoinder and a hope. American Journal of Geriatric Psychiatry, 25(11), 1198.

https://doi.org/10.1016/j.jagp.2017.07.010

\section{Published in:}

American Journal of Geriatric Psychiatry

\section{Citing this paper}

Please note that where the full-text provided on Manchester Research Explorer is the Author Accepted Manuscript or Proof version this may differ from the final Published version. If citing, it is advised that you check and use the publisher's definitive version.

\section{General rights}

Copyright and moral rights for the publications made accessible in the Research Explorer are retained by the authors and/or other copyright owners and it is a condition of accessing publications that users recognise and abide by the legal requirements associated with these rights.

\section{Takedown policy}

If you believe that this document breaches copyright please refer to the University of Manchester's Takedown Procedures [http://man.ac.uk/04Y6Bo] or contact uml.scholarlycommunications@manchester.ac.uk providing relevant details, so we can investigate your claim.

\section{OPEN ACCESS}




\section{Depression trajectories of older Americans and Britons 2002 - 2012: A rejoinder and a hope}

Gindo Tampubolon MSc, PhD* and Asri Maharani MD, PhD

* Corresponding author

Humanities Bridgeford Street Building 2nd floor, Oxford Road, Manchester M13 9PL, United Kingdom, Telephone: +44 1613066959.

We thank Professor Blazer for raising a question not only about our paper but more fundamentally about depression in older ages(1). Let us concede the negative answer. Though we had to work with 8 items CESD scale with its obvious limitations including its inability to capture chronic depression(3). We also had to work with data from a limited period up to 2012, long before 2032. By then one should be able to say with a fairer degree of certainty what happen to the post-War cohort beyond 75 years of age: whether indeed with increasing comorbidities and loss of spouses they soon follow the paths trodden by their predecessors the War and pre-War cohorts.

Until then we should keep the baby, while throwing the bath water. The major point of the paper on secular change or cohort difference stands on firmer ground. Will this ground prove shaky when loss of spouses and comorbidities become more common? In our paper we controlled for these already. Here we refer to extra evidence based on the Britons sample to support our major point. Cohort is fundamentally a shorthand for childhood condition: a similarly named cohort should not be taken to be similar simply because of its name, say the War cohort. A War child in Britain grew up in a different environment from a War child in America. Tampubolon(2) tested the long arm of childhood condition hypothesis and found that childhood condition predicts health outcomes in older ages, across the spectrum from gait speed through episodic memory to mental health (CESD). Childhood can last a life time in Britain. In our paper we noticed these nuanced patterns of secular change on both sides of the Atlantic. Therefore, we emphasised, instead of loss of spouses and comorbidities, the cohort and the childhood condition it stands for. We are now investigating how childhood gets under the skin to have a lasting effect until older ages irrespective of the comprehensive National Health Service or the limited Medicare-Medicaid. For now there is hope in the nuanced trajectories of depression uncovered across cohorts on both sides of the Atlantic.

\section{References}

1. Blazer D. Viewpoint: Do we ever outlive depression? Am J Geriatr Psychiatry, 2017

2. Tampubolon G. Growing up in poverty, growing old in infirmity: The long arm of childhood conditions in Great Britain. PLoS One. 10 (12): e0144722. DOI: 10.1371/journal.pone.0144722, 2015

3. Tampubolon G, Maharani A. When did old age stop being depressing: Depression trajectories of older Americans and Britons 2002 - 2012. Am J Geriatr Psychiatry, 2017

\section{Acknowledgement}

This work was supported by grants from the Medical Research Council and Economic \& Social Research Council (grant no. G1001375/1), the National Institute of Health Research (grant no. ES/L001772/1) and the European Union's Horizon 2020 research and innovation programme (SENSE-Cog project, grant no. 668648) to Gindo Tampubolon. Asri Maharani is supported by SENSE-Cog project. 